\title{
Copgraph beetles in the conservation of the dry forest of the Enrique Quintero Arenas Botanical Garden, UFPS-Ocaña.
}

\author{
Wendy Rocio Soto-Castro ${ }^{1}$, José Julián Cadena-Morales ${ }^{2}$ \\ ${ }^{1,2}$ Universidad Francisco de Paula Santander Ocaña, Ocaña - Colombia \\ ORCID: ${ }^{1}$ 0000-0002-8840-1188, ${ }^{20000-0002-1523-9634}$
}

Received: February 02, 2021.

Accepted: April 14, 2021.

Published: May 01, 2021.

\begin{abstract}
The coprophages are a group of individuals of great importance in the ecological dynamism of natural areas given their specific adaptability of the species and their relationship to their distribution since it influences the quality and quantity of the resources they need for their development. In this sense, a study of mangrove coprophages in the dry inter-Andean forest on the grounds of the Universidad Francisco de Paula Santander Ocaña, as a fundamental basis for the in situ conservation of natural areas. For the taxa collection, it was carried out by random sampling within the area, using Pitfall traps made with 16-ounce vessels; inside they contained alcohol and soapy water for the capture and preservation of the species, where the attractant used was decomposing meat and pig manure. The traps were arranged in four sites (M1, M2, M3, and M4), with 15 traps in each of them. In total 824 individuals were registered, distributed in thirteen species, where the abundant corresponds to Canthidium aurifex, Eurysternus scarabaeus and Canthidium sp with 799 (96.96\%) toral individuals; while 3.4\% (25) of the species with six and one individual correspond to Oryctes nasicornis, Odontotaenius disjunctus, Monochamus sp, Hololepta quadridentata, Calathus fuscipes, Neoathyreus exacavatus, Onthophagus striatulus, Dichotomous sp, Copris lunares, Eurysternus marmoreusIn this way, the differences of two zones are documented, one with acidic to slightly acidic soils and another abundant in phosphates and little organic matter, given that the greater information of coprophages is influenced by environmental variables, in addition this abundance is related to abrupt edges adjacent to agricultural farms, where land tenure has changed the structure and functioning of the landscape typical of anthropic areas.
\end{abstract}

Keywords: Dry forest; Composition; Diversity; Conservation; Environmental variable. 


\section{INTRODUCTIÓN}

Forests represent the ecosystems with the greatest threat in their functionality, tropical and subtropical regions are represented close to $40 \%$, in the same way, $42 \%$ correspond to dry forests, being in danger of deterioration with $50 \%$, threatened by anthropic factors, with elements of fragmentation, agricultural and livestock expansion [1]. The state of dry forests in Colombia is no stranger to this reality since its extension has been reduced by $10 \%$, entering a serious risk, damaging the flora and fauna associated with this type of biome, not to mention that it is one of the ecosystems that lacks information about behavior [2].

Knowledge of biodiversity requires considering the different hierarchical levels of the organization of life (genes, species, populations, communities, and ecosystems), along with their attributes of composition, structure, and functionality [3]. With the loss of diversity, vegetation and soil degradation, insects are strongly affected, suffering from the displacement of the species due to the lack of nutrients and shelter necessary for their subsistence [4].

In the group of insects, the manure coprophagus are a group of representative organisms of the order Coleoptera, constituting the largest and most diverse group [5], about 387,100 species have been described [6]. The coprophagus, because of their great richness and ecological diversity, constitute good indicators of the biodiversity of a territory [7], as they are associated with plant formations where they act as predators, herbivores, pollinators or decomposers of organic matter, in addition to this, They are species with a particular sensitivity to habitat modifications or natural or anthropic alterations in ecosystems presenting restricted ranges of distribution [8], forming an ideal group for the study of biological diversity, however, different experiences prove to be good for establishing ecological strategies for biodiversity conservation [9].

The conservation of biological diversity highlighted in ecosystems and natural habitats, reflected in the recovery and maintenance of species in their natural environments [10], in this way it is necessary to incorporate their initial situation or conservation status in which they are found, where a sustainable use of natural resources, rehabilitation, and restoration of natural areas is reflected in the future, in the same way, the knowledge of fauna and flora $[2]$.

The remnants of the dry forest landscape within the botanical garden are characterized by being a mosaic of vegetation of low size, highlighting two to three well-defined strata, mixed with pastures and areas of natural regeneration [11]. Given the strategy for conservation at present and the lack of information on the dry forest of the institution, in studies of indicators based on co-phagoges, ecological importance based on the BS-T will be highlighted, creating scenarios with a view to conservation and emergence of its valuation. In this way, the objective of the investigation corresponds to give an approximation of the state of conservation that is found in the botanical garden of the Universidad Francisco de Paula Santander, Ocaña, in the same way, identify the species of manure coprophagus existing in the study area and, in turn, recognize the importance of the relationships between the abiotic and biotic component, thus allowing to determine the emerging properties that have been derived from it. [12].

\section{THEORETICAL FRAMEWORK}

Terrestrial ecosystems worldwide have presented a progressive alteration of their structure and composition, thus damaging their functionality. In this way, the case of the tropical dry forest (Bs-T) that is in a critical state is illustrated, despite having high values of endemism and floristic diversity adapted to this environment [13]. On the other hand, they contemplate the presence of wooded covers covered in areas with annual temperature ranges between $17^{\circ} \mathrm{C}$, where evaporation exceeds precipitation, this is between $250 \mathrm{~mm}$ and $2000 \mathrm{~mm}$ per year [14].

Natural groups represent a characteristic of vital importance since they develop in their population a dynamic system between time and their space reflected in the evolutionary variation between the different existing communities within their habitat [15].

Ecosystems have suffered various disturbances over time, from which research has arisen about this component, according to Grime [16] points out this series of articulated events that cause damage to the environment, reducing the increase in biomass, on the other hand, White \& Pickett [17] mentions the direct effects on the structure of ecosystems around its community in general, highlighting the variations in the availability of resources in the environment, in the same way Sousa [15], Barrera \& Ríos [18] categorize these disturbances according to their natural or anthropic origin, highlighting the extensions and magnitudes focused on their sizes and topographic formations. This effect is reflected in the fauna and flora exerted in the transformation of its composition and structure giving rise to become a state of succession mosaics [15], caused alterations in the state of its habitat, in its relations between different organizational levels [19].

In the same way, the insect class corresponds according to its distribution, its habitat according to the quality and quantity of the resources that they need for its development [20], in this way its dynamics is concentrated in the adaptability of the species and their relationship with its surroundings [21].

One of the alternatives that allow to identify the conservation status of an ecosystem is through groups of species sensitive to changes in habitat; known as ecological indicators [22]. In this particular case, the entomofauna (insects) is emphasized, which play an important role within the biomes, since they occupy a large part of the habitat; performing ecological functions [23]. In the group of insects, coprophages beetles of the Coleopteran order have been used as bio indicators of anthropic disturbance, due to their functional relationship in the ecosystem [23], together with their capacity for sensory depressions in habitat change and rapid reproduction [25].

These are recognized for their relationship with obtaining excrement of vertebrates or mammals, being essential in their life cycle [26] and for participating in soil formation, contributing to the aeration, filtration, storage, and cycling of nutrients, benefiting from such way the relationship with your environment [27], The study of the coprophages community in a general context has been a group of extensive research establishing effects of transformation and fragmentation in landscapes taking into account the structure of beetles [28], their ecological importance lies in part in the implementation of Measurable indicators in the context of the assessment in the alteration of the environmental composition, structure, and function. 
Taking as a measure the study of insects and specifically beetles, because of their great abundance and ecological diversity, they constitute good indicators of the biodiversity of a territory [29] and because they are related to environmental factors, determined by the patterns of abundance and distribution of the species [30], [31], not counting their association with plant formations where they act as predators, herbivores, pollinators and decomposers of organic matter, presenting restricted ranges of distribution [32].

Abundance patterns and distributions are related to environmental factors, determined by the different species present, as required by Begon, Towsend, \& Harper [30], and Soberón \& Peterson [31] of which, categorize them in the following ways:

- Factors correlated with altitude, latitude, influencing climate variability, energy inputs, and productivity.

- Independent factors such as habitat disturbance and habitat isolation.

- Biotic factors such as the biological community defining its structure and influencing factors in it.

The studies of climatic variations around models of the community of the coprophagus beetles allow to obtain information on the dynamics of activities carried out by the coprophages, being these sensitive to the factors of the environment, as is the case of temperature, since their biological performance it depends on this [33], by presenting ectotherm conditions, thanks to this measure, research on the distribution and estimation of biodiversity as an ecological importance for ecosystems has increased [34].

\section{METHODOLOGY OR PROCEDURES}

In the inter-Andean dry forest plots of the Universidad Francisco de Paula Santander Ocaña, the beetles were collected in four chosen areas called M1, M2, M3 and M4 (see figure 1), approximately $8570 \mathrm{~m}^{\wedge} 2$ each.

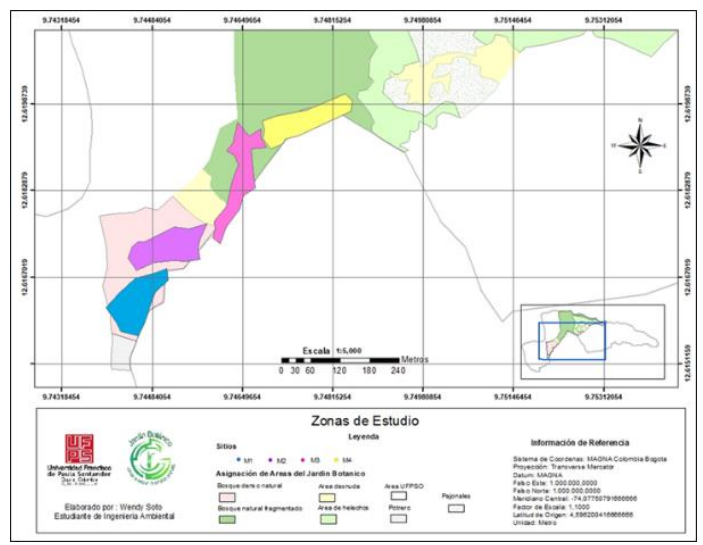

Figure 1: Areas of study in the Botanical Garden.

Source: Own preparation.

With the purpose of obtaining an abundance among the species, the population and sample was constituted by the different coprophagus taxa present in the dry forest of the Garden in the random sampling areas; For this purpose, it was based on the information collection techniques embodied in the diversity inventory manual developed by the Alexander Von Humboldt Biological Resources Research Institute [35]. In this way, the fall traps or "Pitfall" were chosen, they consist of the use of disposable cups of 16 ounces buried at ground level, on the mouth of the container is held with wire at its ends a smaller vessel approximately of 1 ounce inside contained a bait with pig droppings or decomposing meat of which its smell attracted the coprophagus.

The composition of insects was related to the environmental variables temperatures, $\mathrm{pH}$, Relative Humidity, organic matter, CIC, phosphorus and soil texture, to obtain information on the influence of these variables on their abundance and distribution. The tabulation and analysis of the information, regarding Shannon_H, Simpson_1-D, Pielou_J diversity indexes, Jaccard Similarity was determined using PAST software v 3.14 and Estimates v.8.20.

\section{RESULTS, ANALYSIS AND INTERPRETATION}

The area is characterized by varied sub-xerophytic vegetation with herbaceous, shrubby and arboreal formations typical vegetation of lowaltitude dry forests distributed in 31.28 hectares, with an annual rainfall of $1178.6 \mathrm{~mm}$, and temperatures on average of $23^{\circ} \mathrm{C}$.

Sampling performed in the study areas destined, a total of 824 individuals were obtained, recognizing 13 species: Oryctes nasicornis, Odontotaeniu disjunctus, Eurysternus marmoreus, Eurysternus caribaeus, Canthidium sp, Canthidium aurifex, Dichotomius sp, Copris lunaris, Hololepta quadridentata, Onthophagus striatulus, Monochamus sp, Neoathyreus excavatus, Calathus fuscipes.

Table 1: Distribution of Coprophages by sampling sites

\begin{tabular}{|l|r|r|r|r|}
\hline \multirow{2}{*}{\multicolumn{1}{c|}{ Species }} & \multicolumn{5}{c|}{ Study areas } \\
\cline { 2 - 6 } & M1 & M2 & M3 & M4 \\
\hline Oryctes nasicornis & 1 & - & - & - \\
\hline Odontotaenius disjunctus & 1 & - & - & - \\
\hline Eurysternus marmoreus & 1 & 1 & 1 & 2 \\
\hline Eurysternus caribaeus & 34 & 25 & 31 & 39 \\
\hline
\end{tabular}




\begin{tabular}{|l|r|r|r|r|}
\hline Canthidium sp & 23 & 25 & 25 & 13 \\
\hline Canthidium aurifex & 261 & 162 & 106 & 55 \\
\hline Dichotomius sp & 2 & 1 & - & 3 \\
\hline Copris lunaris & 1 & 1 & 1 & - \\
\hline Hololepta quadridentata & - & - & 1 & - \\
\hline Onthophagus striatulus & 1 & - & - & 2 \\
\hline Monochamus sp & - & - & - & 1 \\
\hline Neoathyreus excavatus & 2 & - & - & - \\
\hline Calathus fuscipes & - & 1 & 1 & - \\
\hline
\end{tabular}

Source: Own preparation.

The presence of similar species was observed for all sites reflected by the number of taxa, however, the site with the greatest presence corresponded to M1 with 10 species, followed by M4, M3, and M2 with 7 respective species. When reviewing the Simpson_1-D Index, it was noted that dominance is given by very few species for sites M1 $(0,3471)$ and M2 $(0.415)$, except for M3 (0.5345) and M4 (0.6421) where the dominance is shared, given for the C. aurifex and E. caribaeus species, that is, that the values closest to one represent greater dominance of species and that the values close to zero indicate high diversity.

The Shannon_H index, expresses that the diversity is 1,243 in M4 and in M3 with 1,008 being very low for the sites M1 with 0,7529 and M2 with 0,8206, in the same way, the greater dominance was for M4, but left expressed as the site of greatest conservation within the garden, followed by M3, However, for the interpretation of the Pielou_J index expressed as fairness, corroborating the estimate of the Shannon_ $\mathrm{H}$ index, although this was low for M4 (0.6389), is very similar for M3 (0.518), likewise M1 (0.327) and M2 (0.4217) conduct a similarity, leaving uniformity expressed between the sites represented, check that the fairness is low, already demonstrated in the dissimilarity in the number of individuals per species, leaving a low diversity of coprophagus inside the garden.

Table 2: Diversity indices for each of the sites studied.

\begin{tabular}{|l|r|r|r|r|}
\hline Indexes & M1 & M2 & M3 & M4 \\
\hline Taxa_S & 10 & 7 & 7 & 7 \\
\hline Individuals & 327 & 217 & 166 & 115 \\
\hline Simpson_1-D & 0,3471 & 0,415 & 0,5345 & 0,6421 \\
\hline Shannon_H & 0,7529 & 0,8206 & 1,008 & 1,243 \\
\hline Equitability_J & 1.554 & 1,115 & 1,174 & 1,265 \\
\hline
\end{tabular}

Source: Own preparation.

According to the cluster similarity analysis (see Figure 2), it was observed that with the Jaccard index, the most similar sites correspond to M1-M4 (54\%) and M2-M3 (75\%), however, the Shared taxa were low, which is shown a percentage of 46\%, in this case, it was expected that the sites would be very similar because it is a very homogeneous area in terms of dry, which is reflected in the dissimilarity between M1-M4 and M2-M3 forest vegetation and other environmental variables.

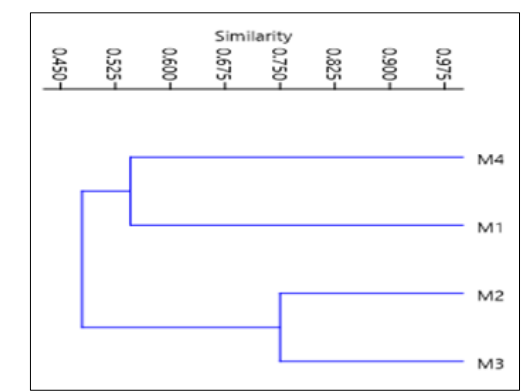

Figure 2: Similarity analysis between sites.

Source: Own preparation.

Likewise, the closeness that exists between the unique and shared species in each site was observed (see Figure 3) and a high distance between the Monochamus sp species, which was unique in the M4 zone with the other clusters. However, there was a lot of closeness between species, although they were unique at each site: O. nasicornis-O. disjunctus (zone M1), H. quadridentata (zone M3).

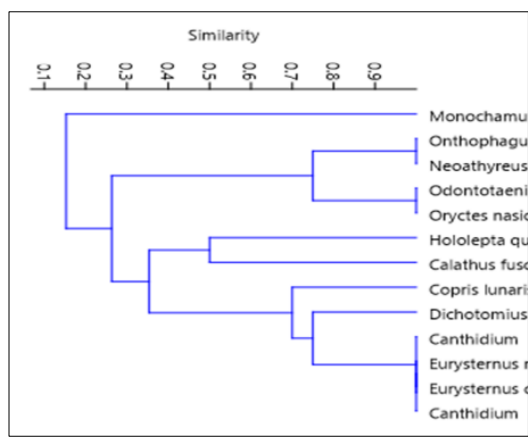

Figure 3: Analysis of Similarity between species. Source: Own preparation. 
On the other hand, the relative humidity was reviewed, showing similar data for the sites, ranging between $55 \%$ and $86 \%$, where it was reflected in soil temperature, ranging between $20.5^{\circ} \mathrm{C}$ and $21^{\circ} \mathrm{C}$; although the ambient temperature behaved between $22^{\circ} \mathrm{C}$ and $31.2^{\circ} \mathrm{C}$, the site with the highest temperature corresponding to the site $\mathrm{M} 2\left(31.2^{\circ} \mathrm{C}\right)$, being similar to M1, M3 and M4 (26.1 $\left.{ }^{\circ} \mathrm{C}\right)$, similarly to similar behavior was marked for low temperatures with $\mathrm{M} 2\left(22.0^{\circ} \mathrm{C}\right)$, and a uniformity for M1, M3, M4 $\left(19.5^{\circ} \mathrm{C}\right)$.

On the other hand, in the $\mathrm{pH}$, which ranged between 4.7 and 5.3 typical of these types of dry soils in Ocaña, but does not reflect a significant contribution in the presence and abundance; however, phosphates corroborated the similarity between M1-M4 with 59.5 mg P2O5 / 100g and M2-M3 with 32.1-27.5 mg P2O5 / 100g, which was reflected in organic matter registering 9.0 -14.7\% for M1-M4 and 3.3\% for M2- M3, therefore two well-defined areas within the Garden were defined.

In the same way an identification of textures was made for each of the sites which presented for M2 and M3 sandy loam soils, which consisted of having a good structure in their particles because they have a higher content of sands, implying a low porosity in their Soils, intervening its drainage in the texture and nutrients are altered, for the sites M1 and M4, sandy loam soils were determined, formed by aggregates in equilibrium concentrations, this condition favors infiltration processes, the flow of water and air inside of the soil, through its macros and micropores.

Likewise, a simple linear regression analysis was performed to relate the attributes of the community (wealth and abundance) with the dependent and independent variables of the ecosystem, using the PAST v program. 3.14.

Tables 3 and 4 show the self-values generated with the program, where they allowed us to identify the dispersion characteristics and their deviations from the records in distribution models in favor of individuals and their relationship with external factors.

Table 3: Linear regression eigenvalues for the variables.

\begin{tabular}{|c|c|c|c|c|}
\hline Variables & M1 & M2 & M3 & M4 \\
\hline Organic material & -23.23 & 36.332 & -52.038 & 0.82565 \\
\hline $\mathrm{CIC}$ & 55.314 & 38.279 & -26.893 & -40.573 \\
\hline $\mathrm{pH}$ & -27.301 & -46.898 & 10.021 & -0.0038378 \\
\hline Match & 47.783 & 33.613 & -9.991 & 36.279 \\
\hline $\mathrm{T}^{\circ} \mathrm{C}$ & 10.832 & 99.294 & 10.243 & 16.495 \\
\hline $\mathrm{RH}^{\circ}$ & -35.003 & -76.817 & -13.297 & -0.14564 \\
\hline $\mathrm{T}^{\circ}$ Floor & 13.948 & 66.018 & 77.329 & 15.381 \\
\hline
\end{tabular}

Source: Own preparation.

Table 4: Linear regression eigenvalues for species.

\begin{tabular}{|l|c|c|c|c|}
\hline \multicolumn{1}{|c|}{ Species } & M1 & \multicolumn{1}{c|}{ M2 } & \multicolumn{1}{c|}{ M3 } & M4 \\
\hline Oryctes nasicornis & -35.324 & -83.761 & -21.069 & -0.50818 \\
\hline Odontotaenius disjunctus & -35.324 & -83.761 & -21.069 & -0.50818 \\
\hline Eurysternus marmoreus & -34.081 & -64.932 & -13.341 & 0.050296 \\
\hline Eurysternus caribaeus & 21.186 & 22.093 & 64.921 & -0.99553 \\
\hline Canthidium sp & 50.188 & -0.95704 & 12.72 & 0.23525 \\
\hline Canthidium aurifex & 293.06 & -24.816 & -15.163 & -0.091686 \\
\hline Dichotomius sp & -33.417 & -59.708 & -2.755 & 0.5665 \\
\hline Copris lunaris & -34.51 & -83.689 & -0.96169 & -0.34846 \\
\hline Hololepta quadridentata & -35.774 & -79.607 & -0.87216 & -0.825 \\
\hline Onthophagus striatulus & -34.895 & -65.004 & -24.793 & -0.10942 \\
\hline Monochamus sp & -35.892 & -72.132 & -17.757 & -0.043282 \\
\hline Neoathyreus excavatus & -34.543 & -86.012 & -26.243 & -0.77369 \\
\hline Calathus fuscipes & -35.292 & -81.438 & -0.44431 & -0.082951 \\
\hline
\end{tabular}

Source: Own preparation.

Taking into account the assigned eigenvalues for environmental variables and species, the percentage of variance for M1 was $94.04 \%$, M2 with $53.918 \%$, M3 with $0.665 \%$ and M4 with $0.6 \%$, taking into account the data collected in zones M1 and M4, a clear link with the CIC and phosphorus parameters was evident, in the same way the species showed a correlation with the parameters of relative humidity, $\mathrm{pH}$ and organic matter, except for Eurysternus caribaeus, since this manifested a deep relationship with the ambient temperature and that of the soil, on the other hand the behavior of the Canthidium aurifex species it did not reflect a link with the variables taken into account for the study, in general the PCA demonstrated a defined grouping. 


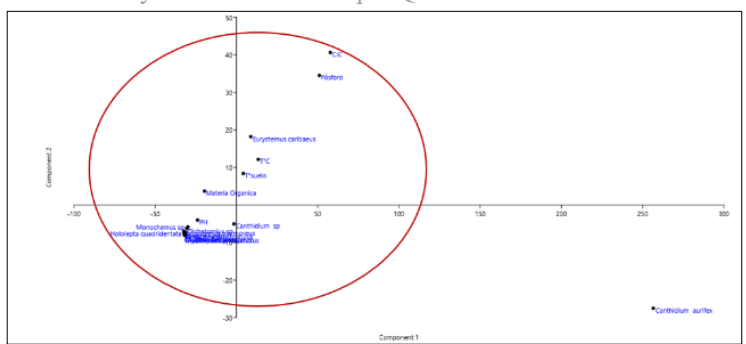

Figure 4: Relationship of species collected and environmental variables M1 and M4. Source: Own preparation.

As for the M2 and M3 sites, it was shown that the Canthidium sp and Eurysternus caribaeus species had a closeness with ambient and soil temperature, repeating the link between organic matter, $\mathrm{pH}$ and relative humidity with the majority of species collected except Canthidium sp, Eurysternus caribaeus and Canthidium aurifex, in the same way, the parameters of CIC and phosphorus were manifested with the Canthidium aurifex species. Being the most distant from the others.

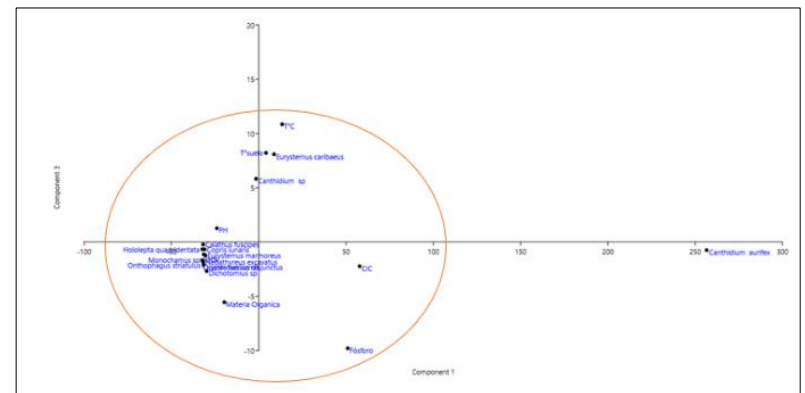

Figure 5: Relationship of species collected and environmental variables M2 and M3. Source: Own preparation.

When comparing the results obtained with others carried out with the same study methodology and in areas where the dry forest prevails, it is obtained that the wealth obtained is similar to that recorded in the town of Cerros de Santa Marta (12 species) and superior to the studies made in Sucre registering between 10 and 11 species as an appointment [36], [37], when confronting the records by the department of Norte de Santander with Orozco and Pérez [37] where they obtained 19 species, marking a difference of 6 species with respect to this, I can demonstrate a similarity between the individuals collected.

The wealth acquired in this research consisted of 13 species, representing 4.59\% of the 283 species registered for Colombia [38]; [39], [39] and $19.12 \%$ of the 68 species deposited and registered in the Collection Entomological of the Alexander Von Humboldt Institute for the dry forest. With the result of 13 species with respect to the other locations, the wealth of coprophagus beetles is low since the average has been recorded between 15 and 35 species [40].

The wealth and abundance values found were similar to those found by Escobar [42] in the Nukak Nature Reserve (Guaviare Department), due to the presence of sandy soils, the solar incidence on the soil surface and the supply of food; In turn, Piera and Torres [43] stated that the scarcity of coprophagus beetles in the sandy plateaus of the Chiribiquete Nature Reserve was related to environmental factors and soil conditions [35], this remnant of dry forest despite presenting erosion in its structure, ranges of 4 to 10 species per area were recorded, housing a representation of the diversity of beetles in the region.

\section{PROPASAL FOR SOLUTION OR IMPROVEMENTS}

According to the results obtained in the research promptly, the emphasis is placed on strengthening strategies for the conservation of biodiversity, which seeks to implement the guidelines, criteria, and indicators that allow the framework for action to be taken to preserve nature. [44], in order to achieve an improvement in the level of conservation of biological diversity and sustainable use of the natural components of the Botanical Garden, given that it is a dry forest protection scenario.

Based on this, environmental conservation strategies are proposed for the areas of greatest conservation, they are suggested:

- Continue with the processes of conservation of biodiversity in situ and ex-situ of the Botanical garden "Jorge Enrique Quintero arenas" in its remnant of dry forest.

- Preserve existing natural habitats taking into account the functionality of the existing biome in the Botanical Garden.

- Protect the diversity of flora and fauna in favor of its functionality, taking into account its distribution and importance in the dry forest of the Botanical Garden

Similarly, for areas with less environmental conservation, the following are proposed:

- Properly preserve the areas of interest for the conservation of biodiversity in situ and ex-situ of the Botanical Garden "Jorge Enrique Quintero arenas" in its remnant of dry forest.

- Protect the fragments of natural habitats as a priority, taking into account the destination of the botanical garden areas for the conservation of the biodiversity of the area.

- Prevent the extinction of the species of flora and fauna existing in the Botanical Garden "Jorge Enrique Quintero Arenas". 
In a general way, it is necessary to promote the linking of the general community in the conservation of biodiversity, with its importance of conservation, threats, behavior of which environmental benefits are promoted and in this way take new habits and environmental awareness [45].

\section{CONCLUSIONS}

According to the collected species, it was obtained that the genus Onthophagus, canthidium and Eurysternos have been located in similar investigations concluding that they are characteristic of dry forests. A representative number was registered with 584 individuals for Canthidium aurifex and 86 individuals for Canthidium sp, being superior to the studies carried out by IAvH [46], Orozco and Pérez [37], for the species Eurysternus caribaeus, an equivalence was registered in all the individuals collected. Similarly, the Canthidium and Eurysternus generates indicated tolerance to different transformation and fragmentation processes within the remnant of the Botanical Garden landscape, highlighting in one way or another being considered characteristic species of the place.

The abundance differences related to the environmental variables were documented, thus determining an abundant composition in surrounding areas on the edge of agricultural ecosystems and the less abundance in more conserved sites within the dry forest cover immersed in the Universidad Francisco de Paula Santander Ocaña.

Regarding diversity, the Margalef index expressed a richness of species for the botanical garden, the Simpson index indicated that the M1 and M2 zones the dominance is given by very few species, for the M3 and M4 sites the dominance is shared by the C. aurifex and E. caribaeus species. According to the Pielou index, which expressed high equity, similarly the similarity expressed by Jaccard confirms the similarities between the sites, but in turn reflects a dissimilarity between M1-M4 and M2.-M3 with a percentage of 46\%, where the sites were expected to be very similar because it is a very homogeneous area in terms of dry forest vegetation and other variables, the area of the botanical garden project expressed two defined areas with respect to its conservation corroborating the biodiversity indices.

Although there is a similarity in the environmental variables, the sites presented different species of coprophagus, which allows two very clear areas to be separated in the Botanical Garden, whose conservation object must be advanced, corresponding to the in situ conservation of the vegetation and flora of each area.

\section{RECOMMENDATIONS}

The recommendations suggested in future research to be carried out, is to take into account the catches for each trap, in this way to have a more detailed view of the overall behavior of the dry forest ecosystem and in this way to make detailed projections of the behavior of the biome.

On the other hand, it is recommended to the directives of the Jorge Enrique Quintero Arenas Botanical Garden, to execute and follow up the environmental management measures for the conservation of the flora and fauna in the dry forest remnant.

Similarly, encourage research by the University for the Knowledge of the Botanical Garden and its region in general, where it is allowed to study the biological wealth that is available and in this way general measures for the conservation of flora and wildlife

\section{REFERENCIAS}

[1] J. Ruiz, y M. C. Fandiño, "Estado del bosque seco tropical e importancia relativa de su flora leñosa, islas de la vieja providencia y santa catalina, Colombia, caribe suroccidental, acedémia colombiana de ciencia, 33 (126) (issn 0370-3908), 5 -15, recuperado de http://www.accefyn.com/revista/Vol_33/126/5-16.pdf. 2009

[2] C. H. Pizano y García. "Bosque Seco Tropical en Colombia". (I. d. Humboldt, Ed.) Bogotá: Ediprint Ltda. 2014

[3] R. Noss, Indicators for monitoring biodiversity: a hierarchical model. Conservation Biology, 4(4), 355-364.

[4] C. F. Medina, Escobar y G. Kattan, Diversity and habitat use of dung beetles in a restored Andean landscape. Biotropica. 34 : $181-187$. 2002

[5] C. Moreno, "Métodos para medir la biodiversidad", M\&T-Manuales y Tesis SEA, vol. 1. Zaragoza, 84 pp, recuperado de http://entomologia.rediris.es/sea/manytes/metodos.pdf. 2001

[6] Z. Q. Zhang, “Animal biodiversity: An introduction to higher-level classification and taxonomic richness” (ISBN 978-1-86977-850-7 ed., Vols. ISSN 1175-5334). Zootaxa. 2011

[7] J. Morrone y A. Ruggiero, ¿Cómo planificar un análisis biogeográfico? Dugesiana, 7(2), 1-8. 2001

[8] C. González, A. Vallarino, J. Pérez, y M. Low, M. (editores) Bioindicadores: guardianes de nuestro futuro ambiental, Colegio de la forntera sur (Ecosur) y Instituto Nacional de ecologia y cambio climatico (INECC)recuperado de http://areasnaturalesprotegidas.org/renanp/pdfs/libros/Dr_Ortiz_Bentonicos_Bioindicadores.pdf 2014

[9] L. Pulido, C. Medina, y R. Riveros, "Nuevos registros de escarabajos coprófagos (Scarabaeidae: Scarabaeidae) para la región Andina de Colombia. Revista Academica Colombiana de Ciencia, 31(119), 305-310, recuperado de esearchgate.net/publication/282660383_NUEVOS_REGISTROS_DE_ESCARABAJOS_COPROFAGOS_SCARABAEIDAE_SCARA BAEINAE_PARA_LA_REGION_ANDINA_DE_COLOMBIA_PARTE_I. (2007)

[10] Baptiste, B. "El bosque seco tropical En colombia. Bogota, Colombia: Instituto de investigación de recursos biológicos Alexander von Humboldt". Obtenido de http:/www.humboldt.org.co/es/investigacion/proyectos/en-desarrollo/item/158-bosques-secos-tropicales-encolombia 2014

[11] E. Amaya-Amaya, y Villamizar. "Jardín botánico Jorge Enrique Quintero Arenas". Ocaña: UFPSO. 2016

[12] T. Santos, y J. Tellería. "Pérdida y fragmentación del hábitat: efecto sobre la conservación de las especies". Ecosistemas. 15 (2): 3-12, recuperado de https://www.ucm.es/data/cont/media/www/pag-33471/2006_Ecosistemas_2_3.pdf. 2006 
[13] R. T. Pennington, y J. A. Ratter, "Neotropical Savannas and Seasonally Dry Forests: Plant Diversity, Biogeography, and Conservation". Boca Raton (1 ed.). Boca Raton. 2006

[14] L. R. Holdridge, Ecology, Photographic supplement prepared by J.A. Tosi Jr., rev. ed. San José, Costa Rica: Tropical Science Center. 1967

[15] W. P. Sousa, The role of disturbance in natural communities, Annual Rewiev Ecological Systematics, Vo 15: 353 - 391 , pp. $353-391$. 1984.

[16] J. Grime, Plant strategies and vegetation processes. Wiley, New York. Pp. 419. White, P. \& S. Pickett. 1985. The ecology of natural disturbance and patch dynamics, Academics Press, Pp. 3-13. 1979.

[17] P. S. White, y T. Pickett, The Ecology of Natural Disturbance and Patch Dynamics, Copyright, ISBN 978-0-12-554520-4, pp 1-472. 1985

[18] I. Barrera, y F. Ríos, "Acercamiento a la ecología de la restauración. Pérez Arbelaezia”. 13: 33 - 46. 2002

[19] T. Schowalter (1985). Adaptations of insects to disturbance. Pp.: 235- 252 In: White, P. \& S. Pickett (Eds). The ecology of natural disturbance and patch dynamics. Academic Press

[20] A. F. Bennett, y J. M. Blanch. Enlazando el paisaje: el papel de los corredores y la conectividad en la conservación de la vida silvestre. San Jose, Costa Rica: UICN. Obtenido de https://www.iucn.org/es/content/enlazando-el-paisaje-el-papel-de-los-corredores-y-laconectitividad-en-la-conservaci\%C3\%B3n-de-la-vida-silvestre. 2004

[21] C. Cultid, C. Medina, B. Martínez, A. Escobar, L. Constantino, y N. Betancur "Escarabajos coprófagos (Scarabainae) del Eje Cafetero: guia para el estudio ecologico" (Vol. 1). Ccaldas, Villa Maria, Colombia. 2012

[22] R. Wilson, J. Trueman, S. Williams, y D. Yeate (2007). Altitudinally restricted communities of Schizophoran flies in Queenslan's wet tropics: vulnerability to climate change. 11(16), 3163-3177. Biodiversity and Conservation.

[23] A. Gonzales, E. Torres, y C. Medina, Escarabajos coprofagos (coleoptera Scarabaeinae) de bosques secos colombianos en la colección Entomologica del instituto Alexander von Humboldt. Pp.1-8. 2015

[24] G. Halffer, y E. Matthews. The natural history of dung beetles of the subfamily Scarabaeinae (Coleoptera, Scarabaeidae). Folia Entomológica Mexicana, 45(2). 1966

[25] L. A. Herrera. Diversidad y distribucion potencial de escarabajos coprófagos (Coleoptera: Scarabaeinae: Scarabaeinae) bajo escenarios de cambio climático en un paisaje fragmentado al sur de Costa Rica [Tesis]. 101. Turrialba, Costa Rica: Centro agronómico tropical de investigación y enseñanza escuela de posgrado. 2009

[26] M. A. Moròn, escarabajos, 200 millones de años de evolucion. Mexico y sociedad Entomológica Aragonesa 21(3),pp 204, recuperado de http://www.scielo.org.mx/scielo.php?script=sci_arttext\&pid=S0065-17372005000300012. 2004

[27] D. Malagón, C. Pulido, R. Llinas, y C. Chamorro. Suelos. de Colombia, origen, evolución, clasificacion, distribucion y uso, Suelos de Colombia.p 456, ISBN 9858-9067-00-X, Instituto Geográfico Agustín Codazzi. 1995

[28] F. Escobar "Estudio de la comunidad de coleópteros coprófagos (Scarabaeidae: Scarabaeidae) en un remanente de bosque seco al norte del Tolima”. Caldasia, 19 (3) (419 - 430). 1997

[29] D. Yeates, P. Bouchard, y G. Monteith. Patterns and levels of endemism in the Australian wet tropics rainforest: evidence from flightless insects. Invertebrate Systematics, (16), 605-619, CSIRO. 2002

[30] M. Begon, C. Towsend, C, y J. Harper, Ecology: from individuals to ecosystems. 4. USA: Blackwell publishing. Carignan, V., \& Villard, M. A. (2002). Selecting indicator species to momitor ecological intedrity: a review. (78), 45-6. 2006

[31] J. Soberón, y Peterson, A. Interpretation of models of fundamental ecological niches and species. 1 - 10. Biodiversity Informatics, 2005.

[32] Jerez, V. Diversidad y patrones de distribucion geografica de insectos coleópteros en ecosistemas desérticos de la región de Antofagasta. Revista Chilena de historia natural, 79-92. 2000

[33] S. Romero, Comportamiento nidificador y ciclo biológico de Onthophagus similis. Boletín sociedad Entomológica Aragonesa, 41(267270), recuperado de http://sea-entomologia.org/Publicaciones/PDF/BOLN41/267_270_BSEA_41_Ontophagus.pdf. 2006

[34] L. A. Herrera, "Diversidad y distribucion potencial de escarabajos coprófagos (Coleóptera: Scarabaeidae: Scarabaeidae) bajo escenarios de cambio climático en un paisaje fragmentado al sur de Costa Rica" [Tesis]. 101. Turrialba, Costa Rica: Centro agronómico tropical de investigación y enseñanza escuela de posgrado. 2009

[35] H. Á. Villareal, Manual de métodos para el desarrollo de inventarios de biodiversidad. Programa de Inventarios de Biodiversidad. Bogotá: Instituto de Investigación de Recursos Biológicos Alexander Von Humboldt. 2004. J. Orozco, y M. Pérez, Escarabajos coprófagos (Coleóptera, Scarabaeidae) del Parque Nacional Los Estoraques (Norte de Santander, Colombia). Revista Brasileira de Entomología, 52(1) 2008

[36] E. Álvarez, Bosque seco tropical Colombia (Vols. 958-96749-6). Banco de occidente, recuperado de https://www.imeditores.com/banocc/seco/creditos.htm. 2006

[37] J. Orozco y M. Perez. Escarabajos coprófagos (Coleoptera, Scarabaeoidea) del Parque Nacional Los Estoraques (Norte de Santander, Colombia). Revista Brasileira de Entonologia, 52(1). 2008.

[38] Medina, C. F. Escobar \& G. Matan. Diversity and hábitat use of dung beetles in a restored Andean landscape. Biotropica. 34 : 181 - 187. 2002.

[39] E. Camero, "Los Escarabajos del Género Eurysternus dalman, 1824 (coleoptera: scarabaeidae) de colombia", Boletin de la Sociedad Entomologica Aragonesa (46), 147-179, $2010 . \quad$ recuperado $\quad$ de $\quad$ http://seaentomologia.org/Publicaciones/PDF/BOLN_46/147_179BSEA46Eurysternus.pdf.

[40] J. Medina, C. Valverde, y M. Wolff. Aspectos ecológicos de Sphaeroceridae (Diptera: Acalytraetae) en el bosque seco tropical del caribe colombiano. Revista Colombiana de entomología, 43(1), Pp.100- 105. 2017

[41] F. Molano, y C. Medina, Especie nueva de Scybalocanthon (Coleóptera: Scarabaeidae: Canthonini) y descripción de la variación del órgano genital masculino. Revista Mexicana de Biodiversidad, 81: 689-699. 2010

[42] F. Escobar, "Diversidad de Coleopteros coprófagos (Scarabaidae: Scarabaeinae) en un mosaico de hábitas en la Reserva Natural Nukak, Guaviare Colombia. Acta Zoológica Mexicana, 79, 103-121. 2000

[43] P. Martín, y A. Torres-Fernández, 1996. Coleópteros de la Sierra de Chiribiquete (Caquetá, Colombia). ELYTRON, 10: 23-50.

[44] MinAmbiente. Politica nacional para la gestion integral de la biodiversidad y sus servicion ecosistemicos (PNGIBSE) (Vols. ISBN:978958-8343-71-6). (s, f).

[45] S. A. Gómez, Componentes del valor del paisaje mediterráneo y el flujo de servicios de los ecosistemas. Ecosistemas, 16(3), 97 - 108, 2007. recuerado de https://core.ac.uk/download/pdf/16361084.pdf. 
[46] Instituto de Investigación de Recursos Biológicos Alexander von Humboldt. Plan de acción regional en biodiversidad, Norte de Santander, Biodiversidad siglo XXI. Cucuta. 2012. Obtenido de http://cedir-catalogo.gestiondelriesgo.gov.co/cgi-bin/koha/opacdetail.pl?biblionumber=11567\&shelfbrowse_itemnumber=10577. 